\title{
TINJAUAN HUKUM ISLAM TERHADAP PEREMPUAN MELAHIRKAN PADA DOKTER KANDUNGAN LAKI-LAKI
}

\section{ZULHAMDI*}

\begin{abstract}
In the examination of the patient, the doctor would see the nakedness of the patient to be examined and not only see the nakedness of the patient but also touch and feel him. Whereas in Islam that same-sex genitalia there are limits that should be seen and touched, especially the opposite sex. This study aims to determine the views of Islamic law against pregnant women who had treatment and gave birth to the male obstetrician. Which at the fact that pregnant women patients either an ultrasound or bore little handled by a male doctor. and even most of the pregnant women are more dominant treatment in gynecologist men compared with a specialist female, This happens mainly because the profession obstetrician is dominated by men and also because many mothers assume that specialists content of more competent men (because physically stronger males), clever and more objective. It is certain pregnant women who had treatment and gave birth to the male obstetrician will reveal his private parts, genitalia fact is something that we must cover both men and women in order to maintain the honor in the eyes of the beholder. So close the genitals was advocated by the religious exception in certain circumstances and conditions which allowed open genitalia.
\end{abstract}

Keywords: Overview of Islamic Law, Specialist Doctors gave birth in Male

\section{PENDAHULUAN}

Islam yang kita lihat akhir-akhir ini telah mengakibatkan gairah keislaman dan membuat kaum muslimin lebih peka dan respon terhadap ajaran-ajaran Islam bukan saja dalam masalah peribadatan tetapi juga dalam bidang kehidupan bermuamalah. Perbuatan, ucapan dan tingkah laku seringkali menjadi perhatian yang lebih besar kalau-kalau ada yang tidak sesuai dengan ajaran Islam lebih-lebih menyimpang dari ajaran Islam, pola perilaku dan kebiasaan baru juga berlaku di kalangan besar kaum muslim. $^{1}$

* Dosen Institut Agama Islam Negeri (IAIN) Lhokseumawe. Email: zoel_hamdi@yahoo.co.id

1 Hasan Hathout, Revolusi Seksual Perempuan. Obstetri dan Ginekologi dalam Tinjauan Hukum Islam (Bandung: Mizan, 1994), hlm. 141. 
Manusia sekarang hidup dalam masa yang berubah sangat cepat sehingga manusia sekarang lebih peka terhadap persoalan-persoalan yang ada. Dengan kemajuan ilmu pengetahuan dan teknologi telah mengubah dan meninggalkan halhal yang dianggap tradisional menuju ke modern, yang diakui sekarang lebih banyak menggunakan tolak ukur keduniawian. Ini terlihat bukan saja dalam masalah peribadatan tetapi juga dalam bidang muamalah dan yang lainnya. Perbuatan atau tingkah laku sekarang menjadi perhatian yang lebih besar dari ajaran Islam kalaukalau ada penyimpangan dari norma-norma agama dan ini berlaku di kalangan kaum muslimin.

Misalkan wanita-wanita jaman sekarang lebih menyukai ahli kandungan (terutama kandungan laki-laki), Dalam kenyataannya dengan cara ini angka kematian bayi dan wanita yang melahirkan dapat ditekan serendah mungkin. Ini adalah perhitungan kasar yang berarti bahwa dari perawatan kebidanan kaum wanita yang sehat tidak lagi meninggal karena sebab kehamilan ataupun bersalin dan bayibayi yang sehat dapat menikmati dunia ini lebih lama. Segala sesuatunya dapat dicapai melalui pengetahuan yang luas, fasilitas yang lebih baik, peralatan yang lebih sempurna dan spesialis yang terus berkembang. Masalah apakah pasien bisa diperiksa secara fisik oleh dokter yang berlainan jenis seringkali menjadi pertanyaan dan perlu mendapatkan penjelasan.

Yang berhubungan dengan kesehatan dalam Islam sangat dijunjung tinggi, baik kesehatan fisik dan mental, maupun kesehatan lingkungan. Hal ini dapat kita ketemukan dalam al-Qur'an dan Sunnah Nabi yang merupakan sumber hukum Islam dan menjadi pedoman hidup bagi seluruh umat Islam.

Ajaran Islam yang berkenaan dengan kesehatan dapat dibagi menjadi tiga macam, yaitu: ${ }^{2}$

1. Islam melarang perbuatan-perbuatan yang dapat membahayakan kesehatan dirinya dan atau orang lain.

2. Islam menyuruh (wajib) atau menyarankan (sunnah) yang mempunyai dampak positif, yakni mencegah penyakit dan menyegarkan atau menyehatkan jasmani dan rohani.

${ }^{2}$ Masjfuk Zuhdi, Masāilul Fiqhiyyah (Jakarta: CV Haji Masagung, 1994), hlm. 188. 
3. Islam menyuruh (wajib) orang yang sakit berobat untuk mengobati penyakitnya.

Islam sangat menghargai tugas kesehatan, karena ini adalah tugas yang sangat mulia, sebab petugas kesehatan menolong sesama manusia yang menderita. Dalam hukum Islam, hubungan dokter dengan pasien adalah hubungan penjual jasa dan pemakai jasa sehingga terjadi akad ijarah antara kedua belah pihak. Pasien dapat memanfaatkan ilmu dan keterampilan dari dokter, sedangkan dokter memperoleh imbalan atas profesinya berupa gaji atau upah jasa. Ini sesuai dengan asas keadilan hukum yang harus dijaga oleh Islam, maka hak-hak dan kewajiban-kewajiban kedua belah pihak harus disesuaikan dengan posisinya masing-masing, makin besar tanggung jawabnya, makin besar pula hak dan kewajibannya. ${ }^{3}$

Dalam pola etika medis sekarang, kepentingan utama seorang dokter ialah kesejahteraan pasien. Dokter sepenuhnya bertanggung jawab atas kesehatan dan keselamatan pasiennya begitupun pasien terikat secara etis pada dokter, dengan asumsi bahwa dokter itu merupakan agen yang mewakili kepentingan pasien. Namun senantiasa ada keterbatasan kemampuan dokter dan keterbatasan pengertian dokter terhadap keadaan pasien. ${ }^{4}$

Dalam pemeriksaan terhadap pasien, dokter pasti melihat aurat pasien yang akan diperiksa bahkan tidak hanya melihat aurat pasien tetapi juga menyentuh dan merabanya. Padahal dalam Islam melihat yang sesama jenis ada batasan-batasan aurat yang boleh dilihat dan disentuh, apalagi melihat yang berlainan jenis.

Pada kenyataannya pasien ibu hamil baik yang melakukan USG (Ultrasonography) ${ }^{5}$ maupun melahirkan tidak sedikit ditangani oleh dokter laki-laki. dan malahan kebanyakan ibu-ibu hamil lebih dominan berobat pada dokter spesialis kandungan laki-laki dibandingkan dengan dokter spesialis perempuan, Hal ini terjadi terutama karena profesi dokter spesialis kandungan lebih didominasi oleh laki-laki dan juga dikarenakan banyak para ibu-ibu menganggap bahwa dokter spesialis

${ }^{3}$ Masjfuk Zuhdi, Masāilul..,hlm. 191.

${ }^{4}$ Benyamin Lumenta. Pelayanan Medis, Citra, Konflik dan Harapan. Tinjauan Fenomena Sosial, (Yogyakarta: Kanisius, 1989), hlm. 32.

${ }^{5}$ USG (Ultrasonography) adalah scan yang menggunakan gelombang suara frekuensi tinggi yang dipancarkan dari kristal bergetar dalam scanner genggam, dengan tujuan untuk mempelajari struktur tubuh internal, gelombang suara atau gema yang dipantulkan kemudian diterjemahkan baik dalam bentuk gambar dua dimensi maupun tiga dimensi pada monitor. 
kandungan laki-laki lebih berkompeten (karena fisik laki-laki lebih kuat), pandai serta lebih objektif.

Dalam praktek kedokteran seorang dokter wajar menerima dan menangani pasien lawan jenis yang bukan mahramnya, lain halnya bila dilihat dari segi hukum Islam seseorang tidak boleh melihat dan menampakkan aurat terhadap lawan jenis yang bukan mahramnya.

Dalam al-Qur'an Allah SWT berfirman An-Nur (24) : 31 :

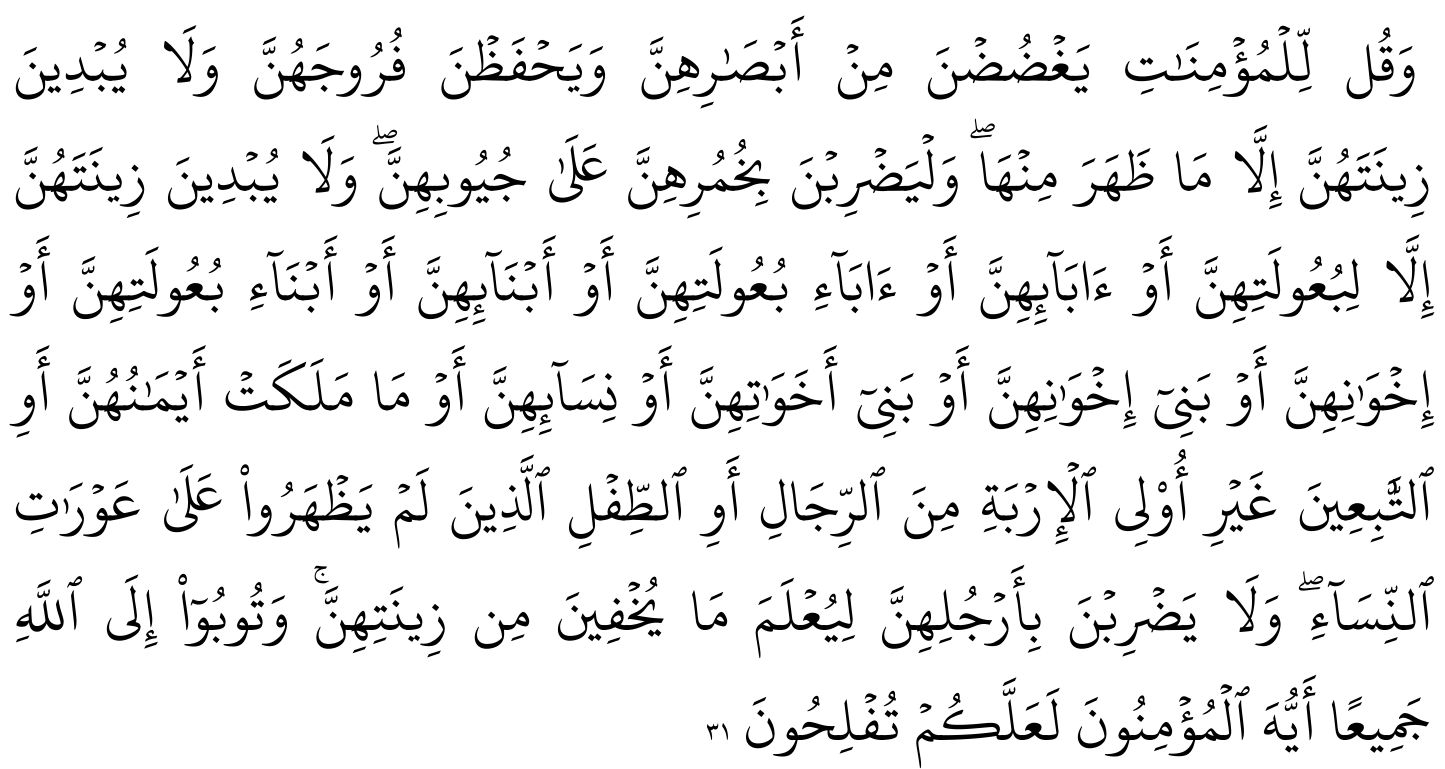

Artinya:

Katakanlah kepada wanita yang beriman: "Hendaklah mereka menahan pandangannya, dan kemaluannya, dan janganlah mereka menampakkan perhiasannya, kecuali yang (biasa) nampak dari padanya. dan hendaklah mereka menutupkan kain kudung ke dadanya, dan janganlah menampakkan perhiasannya kecuali kepada suami mereka, atau ayah mereka, atau ayah suami mereka, atau putera-putera mereka, atau puteraputera suami mereka, atau saudara-saudara laki-laki mereka, atau puteraputera saudara lelaki mereka, atau putera-putera saudara perempuan mereka, atau wanita-wanita Islam, atau budak-budak yang mereka miliki, atau pelayan-pelayan laki-laki yang tidak mempunyai keinginan (terhadap wanita) atau anak-anak yang belum mengerti tentang aurat wanita. dan janganlah mereka memukulkan kakinya agar diketahui perhiasan yang 
mereka sembunyikan. dan bertaubatlah kamu sekalian kepada Allah, Hai orang-orang yang beriman supaya kamu beruntung. ${ }^{6}$

Rasululullah saw bersabda yang artinya "Seorang laki-laki tidak boleh melihat aurat laki-laki lain, begitu juga perempuan tidak boleh melihat aurat perempuan lain, dan tidak boleh seorang laki-laki bercampur dengan laki-laki lain dalam satu pakaian, dan begitu juga perempuan dengan perempuan lain bercampur dalam satu pakaian". 7

Berdasarkan hadits tersebut di atas nampak jelas sesama jenis saja dilarang melihat atau menampakkan auratnya, mafhum muwafaqahnya adalah yang berlawanan jenis lebih-lebih lagi dilarang manampakkan auratnya. Berdasarkan uraian di atas timbul suatu permasalahan bagaimana perempuan hamil melahirkan pada dokter spesialis kandungan laki-laki ditinjau dari hukum Islam dan ketika melihat aurat pasien wanita dalam proses persalinan.

Dari latar belakang masalah beserta ayat dan hadits di atas penulis merasa tertarik untuk meneliti lebih dalam lagi tentang kebolehan ibu hamil melahirkan pada seorang dokter ahli kandungan laki-laki dalam mekanisme kerjanya melihat aurat pasien ditinjau dari segi hukum Islam.

\section{BATASAN-BATASAN AURAT}

Aurat merupakan kata serapan dari bahasa Arab yang berasal dari kara "ara yauru-auran" yang bermakna tampak, lahir, muncul. Kata ini juga bisa bermakna aib/cela, juga bisa bermakna menimbun dengan tanah hingga terhambat mata airnya. ${ }^{8}$ Ini berarti bahwa aurat adalah suatu yang harus ditutup dan ditimbun agar tidak dapat dilihat dan dipandang. ${ }^{9}$ Kata yang bermakna aurat juga ada pada kata "sauah" seperti yang tercantum dalam QS. Thaha ayat 20: 121 yang artinya : "Maka keduanya memakan dari buah pohon itu, lalu nampaklah bagi keduanya aurat-

${ }^{6}$ Al-Qur'an dan Terjemahannya Surat An-Nur (24) : 31

7 Muslim, Sahih Muslim, “Kita al-Haid”(ttp.: Dar al-Fikr, 1981) IV : 30 Hadits/Nomor 209, Hadits Riwayat Muslim dari Abd Ar-Rahman Ibn Abi Sa’id al-Khudriyyi dari ayahnya

${ }^{8}$ Ahmad Warson Munawir, Kamus Al-Munawir (Surabaya: Pustaka Progresif, 1997), hal 984.

${ }^{9}$ Fuad Moh. Fahruddin, Aurat dan Jilbab dalam Pandangan Islam (Jakarta: CV. Pedoman Ilmu Jaya, 1984), hlm10-11. 
auratnya dan mulailah keduanya menutupinya dengan daun-daun (yang ada di) surga, dan durhakalah ${ }^{10}$ Adam kepada Tuhan dan sesatlah ia". ${ }^{11}$

Dalam pengertian istilah, aurat adalah sesuatu yang menimbulkkan birahi atau syahwat, membangkitkan nafsu angkara murka, sedangkan ia mempunyai kehormatan yang dibawa oleh rasa malu supaya ditutupi dan dipelihara dengan tidak mengganggu manusia lainnya, serta menimbulkan kemurkaan, padahal ketentraman hidup dan kedamaian hendaklah dijaga sebaik-baiknya. ${ }^{12}$

Dalam pandangan pakar hukum Islam, aurat adalah bagian dari tubuh manusia yang pada prinsipnya tidak boleh dinampakkan, kecuali dalam keadaan darurat atau kebutuhan yang mendesak. ${ }^{13}$ Rasulullah SAW. juga bersabda yang artinya "Sesungguhnya seorang anak perempuan jika telah haid (baligh), tidak boleh terlihat dari dirinya kecuali wajah dan kedua tangannya hingga pergelangan tangan” (HR Abu Dawud). Dalil-dalil ini dengan jelas menunjukkan bahwa seluruh tubuh wanita adalah aurat, kecuali wajah dan kedua telapak tangannya. Juga dengan jelas menunjukkan bahwa wanita wajib menutupi auratnya, yakni menutupi seluruh tubuhnya, kecuali wajah dan kedua telapak tangannya. ${ }^{14}$

Pengertian di atas dapat kita pahami bahwa aurat merupakan sesuatu yang wajib kita tutupi baik laki-laki maupun perempuan guna menjaga kehormatan di mata orang yang memandangnya. Sehingga menutup aurat itu dianjurkan oleh agama terkecuali dalam keadaan serta kondisi tertentu yang dibolehkan membuka aurat.

\section{PANDANGAN ULAMA TENTANG AURAT PEREMPUAN}

\footnotetext{
${ }^{10}$ Yang dimaksud dengan durhaka di sini ialah melanggar larangan Allah karena lupa, dengan tidak sengaja, sebagaimana disebutkan dalam ayat 115 surat ini. dan yang dimaksud dengan sesat ialah mengikuti apa yang dibisikkan syaitan. kesalahan Adam A.S. meskipun tidak begitu besar menurut ukuran manusia biasa sudah dinamai durhaka dan sesat, karena tingginya martabat Adam A.S. dan untuk menjadi teladan bagi orang besar dan pemimpin-pemimpin agar menjauhi perbuatanperbuatan yang terlarang Bagaimanapun kecilnya.

${ }^{11}$ Al-Qur'an dan terjemahannya Surat Thaahaa 20:121

${ }^{12}$ Fuad Moh. Fahruddin, Aurat dan Jilbab...., hlm 10.

${ }^{13}$ Quraisy Shihab, Jilbab Pakaian Muslimah (Jakarta: 1 Lentera Hati, 2004), hlm 44.

${ }^{14}$ Taqiyudin an-Nabhani, Sistem Pergaulan Dalam Islam, Cet. Ke-3 (Jakarta: Hizbut Tahrir Indonesia, 2007), hlm 66.
} 
Para ulama masih memperdebatkan tentang aurat yang harus ditutupi oleh kaum wanita ketika mereka bertemu dan berinteraksi dengan kaum pria. Di bawah ini akan diuraikan sedikit pendapat ulama tentang aurat perempuan: ${ }^{15}$

a. Pendapat Al-Ahnaf (pengikut Hanafi) berpendapat bahwa wanita boleh membuka muka dan kedua telapak tangan namun pria tetap haram melihat kepadanya dengan pandangan syahwat,

b. Dalam mazhab Maliki terdapat tiga pendapat:

1) Mengatakan wajib menutup muka dan kedua telapak tangan

2) Tidak wajib menutup muka dan kedua telapak tangan, tetapi pria wajib menundukkan pandanganya.

3) Perbedaan cantik dan tidak cantiknya seorang wanita, jika ia cantik maka ia wajib menutup muka dan kedua telapak tangan. Sedangkan wanita yang tidak cantik tidak wajib menutupnya atau disunnahkan.

c. Jumhur (golongan terbesar): Mazhab Syafi'i mengatakan tidak wajib menutup wajah dan kedua telapak tangan sekalipun mereka berfatwa untuk menutupinya.

d. Mazhab Hambali: mengatakan wajib menutup keduanya.

e. Jumhur Fuqaha (golongan terbesar ahli-ahli fiqh) berpendapat bahwa muka dan dua telapak tangan bukan aurat karena itu tidak wajib menutupnya tetapi wajib ditutup jika dirasa tidak aman.

Dari beberapa pendapat ulama mazhab di atas bisa ambil benang merahnya bahwa kebanyakan mereka berpendapat bahwa aurat wanita yang wajib ditutupi adalah seluruh tubuhnya kecuali muka dan telapak tangan saja.

\section{FAKTOR-FAKTOR YANG MEMBOLEHKAN MELIHAT AURAT}

Islam memandang pergaulan antara laki-laki dan wanita sebagai suatu hal yang amat penting. Tetapi bagaimanapun juga, Islam telah menetapkan hukum secara umum mengenai masalah ini. Islam Justru memperhatikan dengan melihat tujuan atau kebaikan yang hendak diwujudkan, atau bahaya yang dimungkinkan, gambarannya dan syarat-syaratnya yang harus dipenuhi atau lainnya. Sebaik-sebaik

${ }^{15}$ Haya binti Mubarok Al-Barik, Ensiklopedi Wanita Muslimah, terj. Amir Hamzah Fachrudin (Jakarta: Darul Falah, 1422 H), hlm 49. 
petunjuk dalam masalah ini ialah petunjuk Rasulullah petunjuk para sahabat yang menjadi pedoman. Orang yang ingin memperhatikan petunjuk ini, niscaya akan tahu bahwa Islam tidaklah memenjarakan kaum wanita atau mengisolasi mereka seperti yang terjadi zaman kemunduran Islam. ${ }^{16}$

Pada dasarnya, QS. An-Nur (24):31 tidak memberikan batasan yang tegas mana aurat wanita yang boleh terlihat di hadapan wanita-wanita kafir. Hanya saja, seorang wanita muslimah mesti menjaga kehormatan dirinya dengan tidak membuka aurat yang tabu (seperti payudara, kemaluan, paha, dan lain sebagainya) di hadapan wanita-wanita kafir. Hendaklah dia mengenakan pakaian yang sopan dan tidak merendahkan maruah dirinya. ${ }^{17}$

Allah telah membolehkan adanya interaksi di antara keduanya, baik dalam kehidupan khusus maupun dalam kehidupan umum. Allah misalnya, telah membolehkan kaum wanita untuk melakukan jual-beli serta mengambil dan menerima barang; mewajibkan mereka untuk menunaikan ibadah haji; membolehkan mereka untuk hadir dalam shalat berjamaah, berjihad melawan orangorang kafir, memiliki harta dan mengembangkannya, dan sejumlah aktivitas lain yang dibolehkan atas mereka. Semua aktivitas di sini yang dibolehkan atau diwajibkan oleh syariah Islam terhadap kaum wanita, harus dilihat dulu. Jika pelaksanaan berbagai aktivitas di atas menuntut interaksi/pertemuan (ijtima') dengan kaum pria, boleh pada saat itu ada interaksi dalam batas-batas hukum syariah dan dalam batas aktivitas yang dibolehkan atas mereka.

Misalnya aktivitas jual-beli, akad tenaga kerja (ijarah), belajar, kedokteran, paramedis, pertanian, industri, dan sebagainya. Sebab, dalil tentang kebolehan atau keharusan aktivitas itu berarti mencakup kebolehan interaksi karena adanya aktivitas-aktivitas itu. Namun, jika pelaksanaan berbagai aktvitas di atas tidak menuntut adanya interaksi di antara keduanya seperti berjalan bersama-sama di jalan umum; pergi bersama-sama ke masjid, ke pasar, mengunjungi sanak-famili, atau bertamasya; dan yang sejenisnya, tidak boleh seorang wanita melakukan interaksi dengan seorang pria. Sebab, dalil-dalil tentang keharusan pemisahan kaum pria dari kaum wanita bersifat umum. Tidak ada satu dalil yang membolehkan adanya

\footnotetext{
${ }^{16}$ Yusuf Qardhawi, Fatwa-Fatwa Kontemporer (Jakarta: Gema Insani, 2006).

${ }^{17}$ Hukum wanita Muslimah menampakkan auratnya di hadapan wanita kafir
} 
interaksi di antara pria dan wanita dalam perkara-perkara di atas, dan interaksi itu pun tidak dituntut oleh perkara yang dibolehkan oleh syariah untuk dilakukan seorang wanita. ${ }^{18}$

Dalam ilmu kedokteran, dikenal sebuah ilmu tentang obstetri dan ginekologi. Ginekologi adalah ilmu kedokteran yang berkenaan dengan fungsi alat tubuh dan penyakit khusus pada perempuan. Salah satunya adalah ilmu kandungan yang merupakan suatu masalah kemanusiaan yang nyata sehingga harus ada justifikasi yang jelas karena ilmu kandungan ini berhubungan langsung dengan masalah aurat yang sifatnya sangat pribadi bagi pasien.

Islam memberikan aturan tentang aurat perempuan yang boleh dilihat dalam hubungan antara laki-laki dan perempuan yang bukan mahram. Aurat perempuan adalah seluruh badan kecuali muka dan telapak tangan. Hal ini dapat dilihat dalam firman Allah SWT Al-Ahzab (33) : 59 :

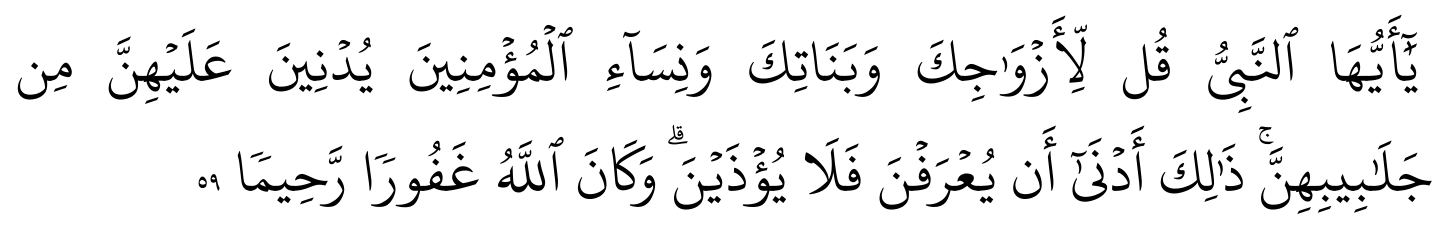

Artinya :

Hai Nabi, Katakanlah kepada isteri-isterimu, anak-anak perempuanmu dan isteri-isteri orang mukmin: "Hendaklah mereka mengulurkan jilbabnya ${ }^{19}$ ke seluruh tubuh mereka". yang demikian itu supaya mereka lebih mudah untuk dikenal, karena itu mereka tidak diganggu. dan Allah adalah Maha Pengampun lagi Maha Penyayang. ${ }^{20}$

Di dalam ayat tersebut Allah SWT memerintahkan agar laki-laki maupun perempuan untuk menutupi anggota tubuhnya dan menahan pandangan agar mereka tidak diganggu. Dengan menutup aurat manusia akan terjaga kehormatannya.

Allah SWT juga berfirman yang artinya "katakanlah kepada wanita yang beriman: "Hendaklah mereka menahan pandangannya, dan kemaluannya..."21 Ayat ini cakupannya sabda Rasulullah saw "Palingkanlah wajahmu“. Di sini terdapat

\footnotetext{
${ }^{18}$ Taqiyudin an-Nabhani Sistem Pergaulan ..., hlm 54.

${ }^{19} \mathrm{Jilbab}$ ialah sejenis baju kurung yang lapang yang dapat menutup kepala, muka dan dada.

${ }^{20}$ Al-Qur'an dan terjemahannya Surat Al-Ahzab (33) : 59

${ }^{21}$ Al-Qur'an dan terjemahannya Surat An-Nur (24) : 31
} 
pengecualian dari pandangan ini yaitu pada waktu-waktu yang terpaksa untuk urusan-urusan mendesak seperti, melihat dengan tujuan pengobatan; Seorang dokter boleh melihat aurat wanita pada tempat-tempat yang memerlukan pengobatan.

Pengobatan dokter laki-laki terhadap wanita diperbolehkan kecuali dengan beberapa syarat: ${ }^{22}$

1. Dokter haruslah orang yang bertakwa, dapat dipercaya, adil, mempunyai keistimewaan dan ilmu pengetahuan pada bidangnya.

2. Jangan membuka bagian-bagian tubuh pasien wanitanya kecuali sesuai dengan keperluan pemeriksaan.

3. Selama pengobatan harus didampingi mahramnya, suami atau wanita yang dapat dipercaya seperti ibunya atau saudara wanitanya.

4. Seorang dokter tidak boleh non muslim selama masih ada yang muslim.

Selain ke empat syarat di atas juga disyaratkan tidak ada dokter wanita yang mampu menangani penyakit yang dialami oleh wanita tersebut. Apabila syaratsyarat tadi terpenuhi maka dokter boleh melihat atau menyentuh bagian-bagian aurat tersebut karena Islam adalah agama yang tidak memberikan umatnya kesukaran namun mengutamakan mashlahat dan kemudahan untuk umatnya. ${ }^{23}$

Dasar hukum hal tersebut adalah firman Allah SWT yang artinya ...Allah menghendaki kemudahan bagimu, dan tidak menghendaki kesukaran bagimu... ${ }^{24}$ Maksud dari ayat tersebut adalah Allah SWT tidak akan memberikan kesulitan bagi umatnya dalam menjalankan ajaran agamanya.

Dalam kaidah fiqh disebutkan laaziraara walaaziraara, kaidah hukum tersebut menjelaskan bahwa tidak boleh menyulitkan orang lain dan tidak boleh pula disulitkan oleh orang lain. ${ }^{25}$

Kewenangan seorang dokter dalam menangani seorang pasien termasuk ke dalam masalah dharuriyyah, karena pembentukan hukum ini semata-mata

${ }^{22}$ Abdul Hamid Kisyik, Bimbingan Islam untuk Mencapai Keluarga Sakinah, alih bahasa Ida Mursida ( Bandung: Penerbit Mizan, 1992 ), hlm. 204-206

${ }^{23}$ Ibid

${ }^{24}$ Al-Baqarah (2): 185

${ }^{25}$ Abdurrahman bin Abi Bakr As-Suyuthi, Al-Asybah Wa an_Nazair(Bairut: Dar Al-Kutub AlIlmiyah, tt) hlm. 165 
dimaksudkan untuk tujuan pemeliharaan agama (hifz ad-din), pemeliharaan keturunan (hifz an-nasl), pemeliharaan jiwa (hifz an-nafs), dan pemeliharaan akal (hifz al- 'aql), pemeliharaan harta (hifz al-mal).

Adapun syarat-syarat untuk bisa dijadikan hujjah adalah: ${ }^{26}$

1. Haruslah merupakan suatu kemaslahatan yang hakiki, dan bukan suatu kemaslahatan yang bersifat dugaan saja.

2. Kemaslahah itu bersifat umum, bukan bersifat perorangan atau kelompok.

3. Pembentukan hukum dengan mengambil kemaslahatan ini tidak berlawanan dengan tata hukum atau dasar ketetapan nash dan ijma'.

Dokter dengan segala perangkatnya, hati (qalbu), mata, telinga, anggota badan, tekhnologi modern serta tempat rawat jalan atau rawat inap, jelas merupakan salah satu tanda kekuasaan Allah SWT yang ditunjukkan kepada manusia di bidang kesehatan. Allah SWT berfirman dalam Yunus (10) : 7 :

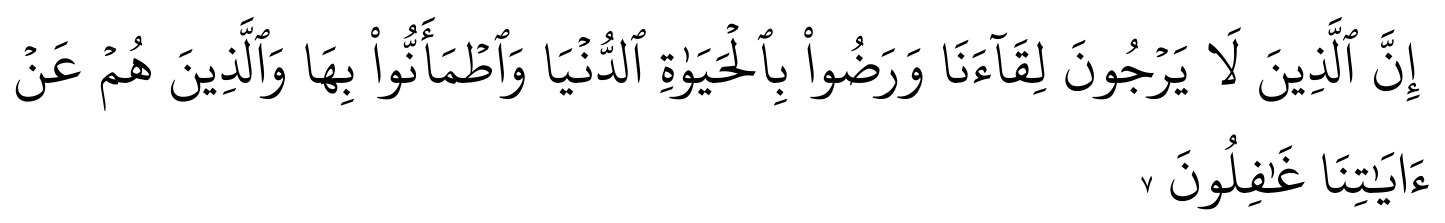

Artinya :

Sesungguhnya orang-orang yang tidak mengharapkan (tidak percaya akan) pertemuan dengan Kami, dan merasa puas dengan kehidupan dunia serta merasa tenteram dengan kehidupan itu dan orang-orang yang melalaikan ayat-ayat Kami.

Yang dimaksud dalam ayat tersebut adalah agar manusia percaya akan adanya pertemuan dengan Allah SWT kelak di akhirat untuk mempertanggung jawabkan amal-amal perbuatannya. Jangan hanya memikirkan kehidupan di dunia saja sehingga kehidupan di akhirat terlupakan. Selanut Allah SWT berfirman dalam Fussilat (41) : 53:

${ }^{26}$ Abdul Wahab Khalaf, Ilmu Usu al-Fiqh (ttp.: Dar al-Qalam, 1978), hlm. 119-120 


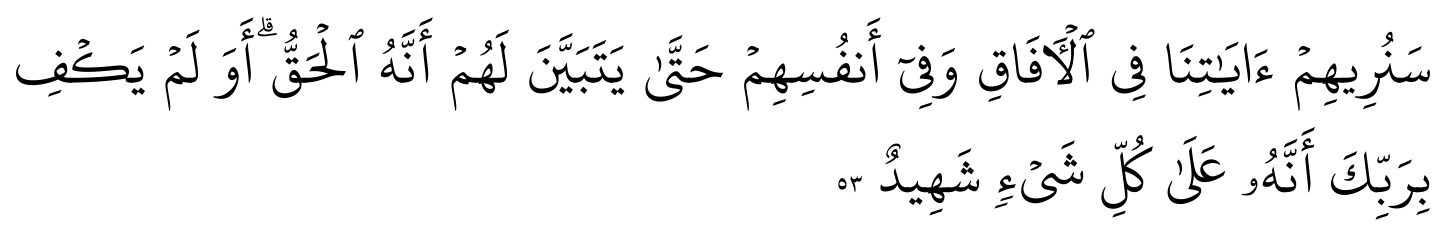

Artinya:

Kami akan memperlihatkan kepada mereka tanda-tanda (kekuasaan) Kami di segala wilayah bumi dan pada diri mereka sendiri, hingga jelas bagi mereka bahwa Al-Qur'an itu adalah benar. Tiadakah cukup bahwa sesungguhnya Tuhanmu menjadi saksi atas segala sesuatu?

Dokter dengan segala ilmu kedokterannya jelas bertugas untuk mendiagnosis

penyakit dan berikhtiar mengobatinya atau melakukan tindakannya yang dibenarkan ilmu kedokteran. ${ }^{27}$

\section{PERSPEKTIF HUKUM ISLAM TENTANG DOKTER KANDUNGAN LAKI-}

\section{LAKI}

Memposisikan Ilmu Kedokteran dalam kerangka ajaran Islam dilihat dari segi sumbernya, Abu al-Ashbal al-Zuhairi secara dikotomis membagi Ilmu atas dua kategori, ilmu syari'at (al-'ilm al-shar'i) dan ilmu kealaman (al-'ilm al-kauni). Sumber'ilm Shar'i adalah al-Qur'an, Hadits, dan Ijmak. Sedangkan Ilmu kealaman merupakan jenis ilmu dari hasil pengamatan, penelitian, percobaan, observasi, dan sejenisnya. ${ }^{28}$

Berdasarkan pembagian ini, posisi ilmu kedokteran termasuk jenis al- ilm alkauni. Dari segi peringkat keutamaannya, sebagian ulama membagi ilmu menjadi 3 kategori: $:^{29}$

a. Tertinggi (al-a'la) yaitu yang bersumber (langsung) dari al-Qur'an dan Hadits.

b. Pertengahan (al-ausat) yaitu ilmu-ilmu duniawi hasil penelitian, pengamatan, observasi, dan sejenisnya, seperti ilmu kedokteran, ilmu hitung, dan sebagainya.

${ }^{27}$ Ahmad Watik Pratiknya. Abdul Salam, M. Sufro (ed. dan pen.). Islam Etika dan Kesehatan. Sumbangan Islam dalam Menghadapi Problem Kesehatan Indonesia Tahun 2000-an (Jakarta: CV. Rajawali,1986), hlm. 75.

${ }^{28}$ Abd. Al-Barr, Jami' Bayan al- 'Ilm wa Fadluh (Kairo: Maktabat Ibn Taimiyat, 1996), hal 37

${ }^{29}$ Ibid 
c. Ilmu rendah (al-asfal) yaitu ilmu-ilmu jenis olah keterampilan, seperti olahraga, menjahit dan sebagainya.

Terlepas dari perbedaan pendapat ulama dalam memposisikan ilmu kedokteran dalam bingkai ajaran Islam bersifat mengikat atau tidak, secara faktual ajaran Islam sangat memperhatikan masalah kedokteran, baik yang bersifat represif maupun preventif (pencegahan). Nampaknya, perbandingan perhatian ajaran Islam terhadap usaha preventif terlihat lebih menonjol, lebih terurai, dan lebih aplikatif seperti dapat dilihat dari peran Rasulullah pembawa risalah yang sangat menekankan kesehatan sebagaimana dijabarkan dalam buku-buku sejarah dan hadits, juga dapat digali dari sisi hikmat al-tashri, ${ }^{30}$

Dalam kehidupan kaum Muslim, dalam segala kondisi mereka secara umum, telah ditetapkan di dalam sejumlah nash syariah, baik yang tercantum dalam alQur'an maupun as-Sunnah bahwa kehidupan kaum pria terpisah dari kaum wanita. Ketentuan ini berlaku dalam kehidupan khusus seperti di rumah-rumah dan yang sejenisnya, ataupun dalam kehidupan umum, seperti di pasar-pasar, di jalan-jalan umum, dan yang sejenisnya. Ketentuan tersebut merupakan ketetapan berdasarkan sekumpulan hukum Islam (majmu' al-ahkam) yang berkaitan dengan pria, wanita, atau kedua-duanya; juga diambil dari seruan al-Qur'an kepada kaum wanita dalam kedudukannya sebagai wanita dan kepada kaum pria dalam kedudukannya sebagai pria. $^{31}$

Terdapat kesenjangan antara pemahaman dokter berkaitan dengan filsafat moral, karena dokter bukan filosof dengan pakar filsafat. Karena itu diperlukan panduan praktis yang merupakan hasil pemikiran mendalam dari filosof, tetapi dapat langsung diaplikasikan tanpa membuat dokter merasa bersalah atau berdosa. Panduan atau pedoman praktis itu termuat dalam kaidah dasar bioetika; sebagian

${ }^{30}$ Hikmat al-Tashri' dalam konteks ini didefinisikan sebagai ilmu yang sahih yang akan menimbulkan kehendak untuk berbuat yang bermanfaat, karena terdapat pandangan dan paham yang dalam tentang hukum-hukum dan rahasia-rahasia persoalan. Menurut definisi lain, sebagai suatu motivasi dalam pensyariatkan hukum dalam rangka mencapai suatu mashlahat atau menolak suatu mafsadat. Lihat 'Ali Ahmad al-Jurjawi, Hikmat al-Tashri' wa falsafatuh, (Beirut: Dar al-Fikr,tth), j. I,5.Muhammad Rasyid Ridla', Tafsir al-Qur'an al-Hakim al-Mashhir bi Tafsir al-Manar, (Beirut: Dar al-Ma'arif, tth), j. III, hlm 310.

${ }^{31}$ Taqiyudin an-Nabhani, Sistem Pergaulan ...hlm 51 
filosof menyebutkannya dengan istilah principalism. ${ }^{32}$ Terdapat 4 kaidah dasar moral (bioetika), meliputi: ${ }^{33}$

a. Menghormati martabat manusia (respect for person/autonomy). Pertama, setiap individu (pasien) harus diperlakukan sebagai manusia yang memiliki otonomi (hak untuk menentukan nasib diri sendiri) dan kedua, setiap manusia yang otonominya berkurang atau hilang perlu mendapatkan perlindungan.

b. Berbuat baik (benefi cence). Selain menghormati martabat manusia, dokter juga harus mengusahakan agar pasien yang dirawatnya terjaga keadaan kesehatannya (patient welfare). Pengertian "berbuat baik" diartikan bersikap ramah atau menolong, lebih dari sekedar memenuhi kewajiban.

c. Tidak berbuat merugikan (non-malefi cence). Praktik kedokteran harus memilih pengobatan yang paling kecil risikonya dan paling besar manfaatnya. Pernyataan kuno: first, do no harm, tetap berlaku dan harus diikuti.

d. Keadilan (justice). Perbedaan kedudukan sosial, tingkat ekonomi, pandangan politik, agama dan paham kepercayaan, kebangsaan dan kewarganegaraan, status perkawinan, serta perbedaan gender tidak boleh dan tidak dapat mengubah sikap dokter terhadap pasiennya. Tidak ada pertimbangan lain selain kesehatan pasien yang menjadi perhatian utama dokter.

Sedangkan menurut kaidah dasar Bioetika Islam meliputi:

a. Kaidah Niat (Qaidah Niyyat).

Prinsip ini meminta dokter agar berkonsultasi dengan hati nuraninya. Terdapat banyak masalah mengenai prosedur dan keputusan medis yang tidak diketahui orang awam. Seorang dokter dapat saja melakukan suatu prosedur dengan alasan yang mungkin masuk akal dari sudut pandang luar, namun sesungguhnya memiliki niatan berbeda dan tersembunyi. Contoh praktis: penggunaan morfin

${ }^{32}$ Gillon R. Medical ethics: four principles plus attention to scope, (BMJ, 1994), 309:184-8

${ }^{33}$ Yusuf Alam Romadhon, Pola Pikir Etika dalam Praktik Kedokteran, CDK-206/ Vol. 40 No. 7, 2013, hlm 549. 
sebagai penghilang rasa sakit pada perawatan kondisi terminal namun niat yang sesungguhnya adalah agar terjadi depresi pernafasan yang akan menyebabkan kematian.

b. Kaidah Kepastian (qaidah al-yaqin).

Tidak ada yang benar-benar pasti (yaqin) dalam ilmu kedokteran, artinya tingkat kepastian dalam ilmu kedokteran tidak mencapai standar yaqin yang diminta oleh hukum. Meskipun demikian diharapkan dokter dalam mengambil keputusan medis, mengambil keputusan dengan tingkat probabilitas terbaik dari yang ada atau yang disebut kedokteran berbasis bukti (evidence based medicine). Termasuk pula dalam hal diagnosa, perawatan medis didasarkan dari diagnosa yang paling mungkin.

c. Kaidah Kerugian (Qaidah al-Darar)

1) Intervensi medis untuk menghilangkan al-darar (luka, kerugian, kehilangan hari-hari sehat pasien)

2) Tidak boleh menghilangkan al-dharar dengan al-dharar yang sebanding (aldharar layuzal bi misthlihi)

3) Keseimbangan antara kerugian dengan keuntungan. Pada situasi intervensi medis yang diusulkan memiliki efek samping, diikuti prinsip bahwa pencegahan penyakit memiliki prioritas yang lebih tinggi ketimbang keuntungan dengan nilai yang sama, dar'an mafasid awla min jalbi al masalih. Jika keuntungan memiliki kepentingan yang jauh lebih tinggi daripada kerugian, maka mendapatkan keuntungan memiliki prioritas yang lebih tinggi.

4) Keseimbangan antara yang dilarang dengan diperbolehkan. Dokter kadang dihadapkan dengan intervensi medis yang memiliki efek yang dilarang namun juga memiliki efek yang diperbolehkan. Petunjuk hukum adalah bahwa yang dilarang memiliki prioritas lebih tinggi untuk dikenali jika keduanya muncul bersamaan dan sebuah keputusan harus diambil, idha ijtima'a al-halal wa al-haram ghalaba al-haram al-halal.

5) Pilihan antara dua keburukan. Jika dihadapkan dengan dua situasi medis yang keduanya akan menyebabkan kerugian dan tidak ada pilihan selain 
memilih salah satu dari keduanya, dipilih yang kurang merugikan, ikhtiyar ahwan al-sharrain. Suatu hal yang merugikan dilakukan untuk mencegah munculnya kerugian yang lebih besar, al-darar al-ashadd yuzalu bi aldharar al-akhaf. Dengan cara yang sama, intervensi medis yang memiliki kepentingan umum diutamakan di atas kepentingan individu, al-maslahat alammah muqoddamat 'ala al-maslahat alkhassat. Individu mungkin harus mendapatkan kerugian untuk melindungi kepentingan umum, yatahammalu al-dharar al-khas il dafi u al-darar al-am. Untuk melawan penyakit menular, pemerintah tidak boleh melanggar/menghilangkan hak-hak umum kecuali ada keuntungan umum yang bisa didapatkan, al-tasarruf 'ala al-raiuyat manutu bi al-maslahat.

\section{d. Kaidah Kesulitan (Qoidah al-Mashaqqat)}

1) Kebutuhan melegalisir yang dilarang. Dalam kondisi yang menyebabkan gangguan serius pada kesehatan fisik dan mental, jika tidak segera disembuhkan, maka kondisi tersebut memberikan keringanan dalam mematuhi dan melaksanakan peraturan dan kewajiban syari'ah.

2) Batas-batas prinsip kesulitan: dalam melanggar syari'ah tersebut tidak melewati batas-batas yang diperlukan (secukupnya saja).

3) Aplikasi sementara dari prinsip kesulitan. Adanya suatu kesulitan tidak menghilangkan secara permanen hak-hak pasien yang harus direkompensasi dan dikembalikan pada keadaan semula seiring dengan waktu; kesulitan melegalisir sementara dari tindakan medis yang melanggar, berakhir setelah kondisi yang menyulitkan tadi berakhir. Dengan kata lain, jika hambatan telah dilewati, tindakan medis yang dilarang kembali menjadi terlarang.

4) Kaidah kebiasaan (Qoidah al-urf); dalam prinsip ini, standar yang diterima secara umum, seperti standard operational procedure (SOP) untuk perawatan klinis dianggap sebagai hukum dan diperkuat oleh syari'ah.

Dalam menentukan hukum pengobatan oleh lawan jenis, sekurangnya ada 4 hal yang menjadi pertimbangan, yaitu berhubungan dengan khalwat, berpandangan dengan lain jenis, melihat aurat pasien, dan terbukanya aib pasien. Masalah yang muncul, biasanya pertimbangan tersebut terkalahkan oleh kelaziman. Pasien 
biasanya dalam berobat, akan memilih orang yang telah teruji kemampuannya dan diyakini akan dapat menyembuhkan penyakitnya tanpa memandang jenis kelaminnya. Dokter atau yang sejenisnya, biasanya dalam melakukan praktik berlaku umum dan professional, tidak melihat jenis kelamin pasiennya. Apalagi bagi dokter yang terikat dengan Kode Etik Kedokteran dalam menunaikan tugasnya tidak dibenarkan membedakan pasien. Masalahnya di sini, dalam praktiknya kadang dituntut melakukan inspeksi (periksa pandang), palpasi (perabaan), perkusi (memukulkan jari kebagian tubuh yang diperiksa), bahkan jika diperlukan mesti melihat atau memegang bagian alat vital pasien, di sinilah masalah yang muncul dari perspektif hukum Islam. ${ }^{34}$

Dokter mengobati secara langsung dengan menyentuh bagian tubuh pasien hukumnya adalah boleh jika dalam keadaan darurat. Mafhum mukhalafahnya, jika tidak dalam keadaan dharurat maka tidak boleh. Metode yang digunakan dalam istinbat hukumnya yaitu dengan menggunakan istihsan ${ }^{35}$ bil maslahah sebagaimana Ulama Hanafi membagi istihsan dengan 6 yaitu:

a. Istihsan Binnas yaitu Istihsan yang didasarkan pada ayat atau hadits. Contoh pada masalah wasiat.

b. Istihsan bil Ijma' yaitu Istihsan yang didasarkan pada ijma'. Contoh Jasa pemandian umum

c. Istihsan bil Qiyas Khofi yaitu Istihsan yang didasarkan pada Qiyas yang tersembunyi. Contoh wakaf lahan pertanian karena adanya hak melewati dan mengalirkan air di atas lahan walau tidak terantum dalam akad.

d. Istihsan bil Mashlahah yaitu Istihsan yang didasarkan pada kemaslahatan. Contoh Bolehnya dokter melihat aurat pasiennya

e. Istihsan bil Urf' yaitu Istihsan yang didasarkan pada adat kebiasaan yang berlaku umum. Contoh penggunaan air pemandian umum yang tidak dibatasi banyaknya.

f. Istihsan bil Dharurah yaitu Istihsan yang didasarkan pada keadaan darurat. Contoh Sumur yang kemasukan najis.

${ }^{34}$ Zuhroni, Desertasi, Respon Ulama Indonesia Terhadap Isu-Isu Kedokteran dan Kesehatan Modern (Jakarta: Sekolah Pasca Sarjana Universitas Islam Negeri Syarif Hidayatullah, 2007), hlm 95.

\footnotetext{
${ }^{35}$ Kecenderungan seseorang pada sesuatu karena menganggapnya lebih baik,
} 
Meskipun demikian, perlu dipahami bahwa bolehnya seorang dokter melihat aurat yang bukan mahramnya perlu dikaji secara mendalam. Kebolehan tersebut harus diikuti tentang prosedur yang ada serta pertanggung jawabannya di hadapan Allah SWT. Hendaklah seorang dokter atau paramedis ketika akan melakukan tindakan pengobatan sebaiknya mengkonsultasikan dulu kepada pihak keluarga guna tidak terjadi fitnah dalam penanganan tersebut.

Kewenangan seorang dokter dalam menangani seorang pasien termasuk ke dalam masalah dharuriyyah, karena pembentukan hukum ini semata-mata dimaksudkan untuk tujuan pemeliharaan agama (hifz ad-din), pemeliharaan keturunan (hifz al-nasl), pemeliharaan jiwa (hifz an-nafs), dan pemeliharaan akal (hifz al- 'aql), serta pemeliharaan harta (hifz al-mal).

Adapun syarat-syarat untuk bisa dijadikan hujjah adalah: ${ }^{36}$

a. Harus merupakan suatu kemaslahatan yang hakiki, dan bukan suatu kemaslahatan yang bersifat dugaan saja

b. Maslahah itu bersifat umum, bukan bersifat perorangan atau kelompok

c. Pembentukan hukum dengan mengambil kemaslahatan ini tidak berlawanan dengan tata hukum atau dasar ketetapan nash dan ijma'.

Maqasid syari'ah bidang kedokteran adalah ditegakkannya hukum dalam Islam secara umum, atau secara khusus tujuan dokter memberikan tindakan promotif, preventif, kuratif dan rehabilitatif pada pasien baik pribadi maupun dalam komunitas adalah untuk: ${ }^{37}$

a. Hifdh al-din (memberikan perlindungan terhadap agama). Tujuan sudut pandang ini adalah memberikan atau meningkatkan hari-hari produktif secara optimal bagi pasien-pasiennya (diciptakan manusia untuk beribadah). Termasuk juga dalam aspek ini adalah menjaga kelurusan aqidah dokternya sendiri, pasien yang dirawat, dan komunitas muslim. Dengan orang yang berbeda agama tetap mengedepankan prinsip toleransi.

${ }^{36}$ Abdul Wahab Khalaf, Ilmu Ushul al-Fiqh (ttp: Dar al-Qalam, 1978), hlm.119-120.

${ }^{37}$ Yusuf Alam Romadhon, Pola Pikir Etika dalam Praktik Kedokteran, CDK-206/ Vol. 40 No.7, 2013, hlm. 548 
b. Hifdh al-nafs (memberikan perlindungan terhadap kehidupan). Tujuannya adalah mempertahankan kehidupan serta mengoptimalkan kualitas hidup pasien dan komunitas. Nafs ini juga diartikan harga diri atau kehormatan pasien yang dirawat.

c. Hifdh al-nasl (memberikan perlindungan terhadap keturunan), Tujuannya adalah mempertahankan keruntutan garis keturunan dan kualitas keturunan. Perawatan antenatal, perinatal, dan post natal termasuk dalam usaha memberikan perlindungan terhadap kualitas keturunan. Perawatan infertilitas juga dalam maksud yang sama demikian juga dengan mendidik remaja agar menjadi orang tua yang berkualitas.

d. Hifdh al-'aql (memberikan perlindungan terhadap akal sehat). Tujuannya adalah mengoptimalkan kualitas intelektual, kecerdasan emosional dan aspek-aspek kecerdasan lainnya bagi setiap penderita ataupun komunitas yang menjadi tanggungjawab dokter. Perawatan terhadap kelainan jiwa, seperti gangguan kecemasan, depresi, psikotik serta kecanduan obat-obatan dan alkohol, dengan berusaha mengembalikan fungsi-fungsi luhur otak pada taraf yang paling optimal, serta berusaha mengkampanyekan hidup tanpa obat dan alkohol adalah termasuk dalam hal ini.

e. Hifdh al-mal (memberikan perlindungan terhadap kekayaan pribadi). Tujuan sudut pandang ini adalah dokter ketika bekerja tidak saja mempertimbangkan efektifitasnya saja tetapi juga harus mempertimbangkan efisiensi atau keekonomisan suatu tindakan diagnosis atau terapi.

Dalil yang menjelaskan kebolehan seorang dokter mengobati seorang pasiennya dalam keadaan darurat adalah hadits pada saat Nabi pergi berperang.

Artinya: "Telah menceritakan kepada kami 'Ali bin 'Abdillah: telah menceritakan kepada kami Bishr bin Al-Mufadldlal: telah menceritakan kepada kami Khalid bin Dzakwan, dari Ar-Rubayyi' bintu Mu'awwidh, ia berkata: "Kami pernah bersama Rasulullah shallallahu 'alaihi wa sallam (dalam 
satu peperangan), memberi minum, mengobati orang-orang yang terluka, serta memulangkan jenazah ke Madinah. ${ }^{38}$

Artinya: "Telah menceritakan kepada kami Yahya bin Yahya: Telah mengabarkan kepada kami Ja'far bin Sulaimaan, dari Thabit, dari Anas bin Malik, ia berkata: "Dulu Rasulullah shallallahu 'alaihi wa sallam berperang dengan membawa serta Ummu Sulaim dan beberapa wanita Anshar lain bersama beliau. Apabila beliau berperang, mereka (para wanita) memberi air untuk minum dan mengobati pasukan yang terluka"39

Dalam batasan-batasan tertentu, para ulama membolehkan seorang dokter atau para medis melakukan pemeriksaan terhadap pasien yang bukan mahramnya jika tidak ada seorang dokter yang mahramnya. Ibnu Abidin berkata: Dalam kitab AlJauharah disebutkan: "Jika penyakit tersebut menyerang seluruh tubuh si wanita maka dokter boleh melihatnya saat pengobatan, kecuali alat kelamin yang vital. Sebab hal itu termasuk darurat. Jika tempat yang sakit adalah kemaluan, maka hendaknya diajari seorang wanita lain untuk mengobatinya. Jika tidak ada juga sementara keselamatan jiwanya sangat mengkhawatirkan atau dikhawatirkan tertimpa penyakit yang tidak mampu ia tahan, maka hendaklah mereka menutup seluruh tubuhnya kecuali tempat yang sakit itu (yakni kemaluan) lalu dipersilakan dokter mengobatinya dengan tetap menahan pandangan semampunya kecuali terhadap bagian yang tengah diobati", ${ }^{40}$

Demikian pula dibolehkan bagi para perawat orang sakit untuk mewudhu'kan atau membantu istinja'nya meskipun yang dirawat seorang wanita. ${ }^{41}$ Muhammad Fu'ad berkata: Di antara dalil yang menunjukkan bolehnya kaum pria mengobati kaum wanita dengan batasan-batasan yang telah disebutkan tadi adalah sebuah hadits yang diriwayatkan oleh Imam Al-Bukhari dari Ar-Rubayyi' binti Mu'awwidhia berkata: "Kami pernah berperang bersama Rasulullah Shallallahu 'Alaihi wa Sallam. Tugas kami adalah memberi minum dan membantu pasukan, dan membawa pasukan yang tewas dan terluka ke Madinah". ${ }^{2}$

${ }^{38}$ Diriwayatkan oleh Al-Bukhaari No. 28

${ }^{39}$ Diriwayatkan oleh Muslim No. 1810

${ }^{40}$ Raddul Mukhtar V/237 dan lihat juga Al-Hidayah Al-'Aladiyah, hlm.245

${ }^{41}$ Lihat kitab Ghidzaaul Albab I/97

${ }^{42}$ H.R Al-Bukhari VI/80 \& X/136, lihat Fathu Bari. Diriwayatkan juga oleh Imam Muslim dari Anas V/196, Abu Dawud VII/205, lihat 'Aunul Ma'bud, dan Imam At-Tirmidzi V/301-302, ia berkata: Hadits ini Hasan Shahih 
Imam Al-Hafidz Ibnu Hajar Al-Asqalani berkata: "Hukum bolehnya kaum pria mengobati kaum wanita diambil secara implisit. Imam Al-Bukhari tidak menegaskan hukum tersebut karena masih ada kemungkinan hal itu terjadi sebelum turunnya ayat yang memerintahkan berhijab. Atau masing-masing wanita ketika itu hanya mengobati suaminya atau mahramnya saja. Secara umum hukumnya: kaum wanita boleh mengobati kaum pria pada saat-saat darurat, dan harus dibatasi sesuai kebutuhan khususnya berkaitan dengan melihat dan memegang pasien atau semisalnya. ${ }^{43}$

Pada intinya ada kesamaan pandangan ulama, diperbolehkan melihat bagian tubuh pasien yang mana saja untuk kepentingan pengobatan, dan untuk menghindari adanya fitnah, disarankan didampingi mahram atau orang yang dapat dipercaya. 'Illat pengharamannya karena akan mengundang fitnah, atau akan terjadi perzinaan, merupakan upaya preventif (sad al-dzari'at). Berdasarkan kaidah fiqhiyyat bahwa pengharaman karena sad al-dzari'at dibolehkan untuk kemaslahatan. ${ }^{44}$

\section{PENUTUP}

Profesi dokter kandungan laki-laki ditinjau dari perspektif hukum Islam, pada dasarnya tidak dibolehklan "diharamkam" karena objek dari dokter kandungan adalah wanita, dan dalam Islam jelas melarang wanita menampakkan aurat sesama jenisnya apalagi menampakkan aurat kepada berlawanan jenis yang bukan mahramnya, kecuali tidak ada dokter kandungan perempuan yang bisa menangani kehamilan tersebut dan sejalan dengan pandangan ulama yang membolehkan untuk melihat bagian tubuh pasien yang mana saja untuk kepentingan pengobatan, namun untuk menghindari adanya fitnah, disarankan didampingi mahram atau orang yang dapat dipercaya. 'Illat pengharamannya karena akan mengundang fitnah, atau akan terjadi perzinaan, merupakan upaya preventif (sad al-dzari'at). Berdasarkan kaidah fiqhiyyat bahwa pengharaman karena sad al-dzari'at dibolehkan untuk kemaslahatan.

\footnotetext{
${ }^{43}$ Lihat kitab Fathul Bari X/136

${ }^{44}$ Lihat 'Ali Ahmad al-Nadzawi, al-Qawaid al-Fiqhiyyat (Damaskus: Dar al-Qalam, 1994),
} hlm. 155 
AL-QADHA Jurnal Hukum Islam Dan Perundang-undangan

Selain itu, ada beberapa syarat yang diperhatikan ketika seorang dokter lakilaki akan mengobati pasiennya yang wanita, diantaranya adalah:

1. Tidak ada dokter wanita yang mampu menangani penyakit yang dialami oleh wanita tersebut

2. Dokter harus bertakwa kepada Allah, dapat dipercaya, adil, mempunyai keistimewaan dan ilmu pengetahuan pada bidangnya.

3. Jangan membuka bagian-bagian tubuh pasien wanitanya kecuali dengan keperluan pemeriksaan.

4. Selama pengobatan harus didampingi mahramnya, suami atau wanita yang dapat dipercaya seperti ibunya atau saudara wanitanya.

5. Seorang dokter tidak boleh non muslim selama masih ada yang muslim.

Apabila syarat-syarat tadi terpenuhi maka dokter boleh melihat atau menyentuh bagian-bagian aurat tersebut yang diperlukan. Hal ini dipandang sebagai manifestasi dari Islam adalah agama yang tidak memberikan kesukaran, namun mengutamakan maslahat dan kemudahan untuk ummatnya. 


\section{DAFTAR PUSTAKA}

Ahmad Warson Munawir, Kamus Al-Munawir, Surabaya: Pustaka Progresif, 1997.

Ahmad Watik Pratiknya. Abdul Salam, M. Sufro (ed. dan pen.). Islam Etika dan Kesehatan. Sumbangan Islam dalam Menghadapi Problem Kesehatan Indonesia Tahun 2000-an, Jakarta: CV. Rajawali,1986.

Al-Barr, Abd. Jami’ Bayan al- 'Ilm wa Fadluh. Kairo: Maktabat Ibn Taimiyat, 1996.

Al-Din, Muwaffiq. al-Tibb min al-Kitab wa al-Sunnat. Beirut, Dar al-Ma'rifat, 1996.

Al-Hanbali, Ibn Muflih. Adab ash-Shar'iyyat.tt; 'Alam al-Kutub, tth, j, II.

Al-Jurjawi, 'Ali Ahmad. Hikmat al-Tashri' wa falsafatuh. Beirut: Dar al-Fikr, tth, j.I.,

Al-Mughni VII/459 dan kitab Ghadzaaul Albab I/97.

Al-Nadzawi, 'Ali Ahmad.al-Qawa'id al-Fiqhiyyat. Damaskus: Dar al-Qalam, 1994.

An-Nabhani, Taqiyudin. Sistem Pergaulan Dalam Islam, Cet. Ke-3. Jakarta: Hizbut Tahrir Indonesia, 2007.

As-Suyuti, Abdurrahman bin Abi Bakr. al-Ashbah wa an Nazair. Beirut: Dar alKutub al-'Ilmiyah.

Benyamin Lumenta. Pelayanan Medis, Citra, Konflik dan Harapan. Tinjauan Fenomena Sosial, Yogyakarta: Kanisius, 1989.

Fuad Moh. Fahruddin. Aurat dan Jilbab dalam Pandangan Islam. Jakarta: CV. Pedoman Ilmu jaya, 1984.

Gillon R. Medical Ethics: Four Principles Plus Attention to Scope, BMJ, 1994.

Hasan Hathout, Revolusi Seksual Perempuan. Obstetri dan Ginekologi dalam Tinjauan Hukum Islam, Bandung: Mizan, 1994.

Haya binti Mubarok Al-Barik, Ensiklopedi Wanita Muslimah, terj. Amir Hamzah Fachrudin Jakarta: Darul Falah, 1422 H.

Khalaf, Abdul Wahab. Ilmu Usul al-Fiqh. ttp: Dar al-Qalam, 1978.

Kisyik, Abdul Hamid. Bimbingan Islam untuk Mencapai keluarga Sakinah, alih bahasa Ida Mursida. Bandung, Penerbit Mizan, 1992. 
Manzur, Ibnu. Lisan al-Arab, Jilid 9.

Moleong, Lexy J. Metodologi Penelitian Kualitatif, cet. ke-28. Bandung: Remaja Rosdakarya, 2010.

Muhammad Rasyid Ridla', Tafsir al-Qur'an al-Hakim al-Mashhir bi Tafsir alManar. Beirut: Dar al-Ma'arif, tth. j. III.

Mukhtar, Raddul, V/237 dan lihat juga Al-Hidayah Al-'Alaiyah.

Munawir, Ahmad Warson. Kamus Al-Munawir. Surabaya: Pustaka Progresif, 1997.

Muslim, Sahih Muslim, "Kita al-Haid” ttp.: Dar al-Fikr, 1981 IV: 30 Hadits/Nomor 209

Nasution, Haroen. Ushul Fiqh. Logos Publising Hoese, 1996.

Qardhawi, Yusuf. Fatwa-Fatwa Kontemporer. Jakarta: Gema Insani, 2006.

Qardhawi, Yusuf. Fiqh Wanita Segala Hal Mengenai Wanita, Cet. Ke-1. Bandung: Jabal, 2006.

Russell, Bertrand, dalam Husein Shahab.Jilbab Menurut al-Qur'an dan al-Sunnah. Bandung: Mizan, 2002.

Romadhon, Yusuf Alam. Pola Pikir Etika dalam Praktik Kedokteran. CDK-206/ vol. 40 no. 7, 2013.

Shihab, Quraisy, Jilbab Pakaian Muslimah, Jakarta: Lentera Hati, 2004.

Sugiyono. Metode Penelitian Pendidikan: Pendekatan Kuantitatif, Kualitatif, dan $R \& D$, cet. ke-11. Bandung: Alfabeta, 2010

Zuhroni. Respon Ulama Indonesia Terhadap Isu-Isu Kedokteran dan Kesehatan Modern. Disertasi, Jakarta: Sekolah Pascasarjana Universitas Islam Negeri Syarif Hidayatullah, 2007 